\title{
Tinjauan Hukum Ekonomi Syariah terhadap Implementasi Peraturan Walikota Bandung Nomor 117 Tahun 2008 tentang Penerapan Tarif Jasa Perusahaan Daerah Pasar Bermartabat Kota Bandung di Pasar Andir Bandung
}

\author{
Agrie Satrya, Asep Ramdan Hidayat, Panji Adam Agus Putra \\ Program Studi Hukum Ekonomi Syariah, Fakultas Syariah, Universitas Islam Bandung \\ Jl. Tamansari No. 140116 \\ 1agriestrya007@gmail.com,2AsepRamdhanHidayat@unisba.ac.id,3PanjiAdamAgusPutra@unisba.ac.id
}

\begin{abstract}
Abstarct-The City Government of Bandung issued Bandung Mayor Regulation Number 117 Year 2008 concerning Establishment of Bandung City Dignified Market Service Company Tariffs, When the kiosk rental agreement between tenants and the market, the market had given leaflets containing kiosk rates including cleaning etc. However, after 4 weeks of rental period, a new leaflet appeared regarding the increase in rental rates for kiosks including kekishan etc. and is no longer in accordance with Mayor Regulation Number 117 Year 2008 in Articles 11 and 12. This research aims to Know the Implementation of Market Management Services Tariffs contained in Bandung Mayor Regulation Number 117 of 2008 concerning Establishment of Company Services in the City of Bandung Dignified Market Area, to find out the implementation of market management service tariffs in the Andir Bandung market in Sharia Economic Law. This research method uses qualitative analysis with a normative juridical approach, which is to look at the tariffs determined in the Andir Bandung market with the market rates determined by the Mayor of Bandung Regulation No. 117/2008 concerning the Determination of Company Services in the Dignified Market Area of Bandung. Based on the findings in the field there is a mismatch between the intentions of the initial agreement with the implementation in the field and the non-compliance with the terms and conditions of the lease according to the HES itself making the Bandung andir market management service tariffs invalid and unjustified.
\end{abstract}

\section{Keywords-Sharia Economic Law, Ijarah, Services, Rates}

Abstrak-Pemerintah Kota Bandung mengeluarkan Peraturan Walikota Bandung Nomor 117 Tahun 2008 tentang Penetapan Tarif Jasa Perusahaan Daerah Pasar Bermartabat Kota Bandung, Saat akad sewa kios antara penyewa dan pihak pasar, pihak pasar telah memberikan selebaran berisi tarif kios termasuk kebersihan dll. Namun setelah 4 minggu masa sewa, muncullah selebaran baru mengenai kenaikan tarif sewa kios termasuk keberishan dll dan sudah tidak sesuai lagi dengan Peraturan Walikota Nomor 117 Tahun 2008 yang ada dalam Pasal 11 dan 12. Penelitian ini bertujuan untuk Mengetahui Implementasi Tarif Jasa Pengelolaan Pasar yang terdapat di dalam Peraturan Walikota Bandung Nomor 117 tahun 2008 tentang Penetapan Tarif Jasa Perusahaan Daerah Pasar Bermartabat Kota Bandung, untuk mengetahui implementasi tarif jasa pengelolaan pasar di pasar Andir Bandung dalam Hukum Ekonomi Syariah. Metode penelitian ini menggunakan analisis kualitatif dengan pendekatan yuridis normatif yaitu untuk melihat tarif yang ditentukan di pasar Andir Bandung dengan tarif pasar yang ditentukan oleh Peraturan Walikota Bandung Nomor 117 Tahun 2008 tentang Penetapan Tarif Jasa Perusahaan Daerah Pasar Bermartabat Kota Bandung. Berdasarkan temuan dilapangan terdapat ketidaksesuaian antara maksud diawal perjanjian dengan implementasi di lapangan dan tidak terpenuhinya rukun dan syarat dari sewa menyewa menurut HES itu sendiri membuat tarif jasa pengelola pasar andir Bandung ini tidak sah dan tidak dapat dibenarkan.

Kata Kunci : Hukum Ekonomi Syariah, Ijarah, Jasa, Tarif

\section{PENDAhUluaN}

Dalam mekanisme pasar, pengelolaan dapat dilaksanakan secara efektif dan profesional ditulis dalam Peraturan Walikota. Peraturan Walikota adalah jenis peraturan perundang-undangan yang ditetapkan oleh walikota. Peraturan walikota ini berlaku untuk semua masyarakat yang ada di kota tersebut dan harus di implementasikan kepada masyarakat, agar masyarakat bisa mengerti, mengetahui dan menaati peraturan-peraturan yang ada di daerahnya masing-masing

Dalam hal ini, Pemerintah Kota Bandung mengeluarkan Peraturan Walikota Bandung Nomor 117 Tahun 2008 tentang Penetapan Tarif Jasa Perusahaan Daerah Pasar Bermartabat Kota Bandung, untuk membiayai keberadaan pasar seperti biaya pembangunan, biaya operasional, biaya pemeliharaan, biaya kebersihan dan biaya keamanan maka perlu ditetapkan besaran tarif jasa pengelolaan pasar. Ada berberapa macam tarif jasa pengelolaan pasar perharinya yang terdapat pada Peraturan Walikota Bandung ini antara lain jasa kebersihan Rp.700,perhari1, jasa ketertiban dan keamanan Rp.500,- perhari,2 
maka jika ditotalkan tarif jasa pengelolaan pasar perharinya yang dibayarkan oleh pengguna jasa atau pedagang kepada agen pengelola pasar adalah Rp.1200,perhari.

Saat akad sewa kios antara penyewa dan pihak pasar, pihak pasar telah memberikan selebaran berisi tarif kios termasuk kebersihan dll. Namun setelah 4 minggu masa sewa, muncullah selebaran baru mengenai kenaikan tarif sewa kios termasuk keberishan dll dan sudah tidak sesuai lagi dengan Peraturan Walikota Nomor 117 Tahun 2008 yang ada dalam Pasal 11 dan 12. sehingga timbul rasa ketidakrelaan beberapa pedagang terhadap pembayaran pungutan tarif jasa pengelolaan pasar yang tidak sesuai dengan Peraturan Walikota Nomor 117 Tahun 2008 yang ada dalam Pasal 11 dan 12, serta hal ini pun bertentangan dengan syarat sah sewa menyewa (Ijarah) menurut Hukum Ekonomi Islam itu sendiri.

\section{LANDASAN TEORI}

\section{A. Ijarah}

Ijarah menurut syara adalah akad yang berisi pemberian suatu manfaat berkompensasi dengan syaratsyarat tertentu. Ijarah bisa juga didefinisikan sebagai akad atas manfaat yang dikehendaki, diketahui, dapat diserahkan, dan bersifat mubah dengan kompensasi yang diketahui.3 Akan tetapi akad ijarah terikat akan beberapa rukun dan syarat yang mana semua rukun dan syarat tersebut harus terpenuhi. Rukun ijarah:

1. Aqiadain adalah kedua belah pihak yang berakad.

2. Ma'qud 'alaih adalah barang atau jasa yang akan disewakan.

3. Ujrah adalah upah atas suatu pekerjaan atau biaya sewa atas suatu barang.

4. Shigat adalah tercapainya akad melalui ijab dan Kabul.

Syarat ijarah:

1. Syarat wujud adalah syarat yang mengatur mengenai para pelaku akad dan mengatur kelangsungan akad itu sendiri.

2. Syarat an-Nafadz adalah adanya hak kepemilikan atau kekuasaan atas suatu benda.

3. Syarat sah adalah syarat yang mengatur mengenai kerelaan kedua pelaku akad, dan pemanfaatan objek akad.4

Sistem ekonomi Islam tidak mengenal adanya kesepakatan perjanjian atau akad dimana salas satu pihak merasa tidak ridho atau terpaksa, sebagaimana yang telah dipaparkan dalam kaidah fikih berikut ini:

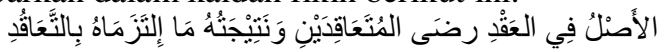

"Hukum asal dalam transaksi adalah keridhaan kedua belah pihak yang berakad, hasilnya adalah berlaku sahnya yang diakadkan".5

\section{B. Tarif Jasa Pengelolaan Pasar dalam Hukum Ekonomi Syariah}

Dalam pemikiran Islam menurut An-Nabahan pemerintah merupakan lembaga formal yang mewujudkan dan memberikan pelayanan yang terbaik kepada semua rakyatnya. Pemerintah mempunyai segudang kewajiban yang harus dipikul demi mewujudkan kesejahteraan masyarakat, salah satunya bertanggungjawab terhadap perekonomian.Upaya mewujudkan dan memberikan pelayanan publik kepada masyarakat sebagai tanggung jawab pemerintah agar menciptakan kesejahteraan pemerintah memiliki kebijakan fiskal yang digunakan untuk mengatur pemerintahannya.

Tujuan dan kebijakan fiskal dalam Islam adalah untuk menciptakan stabilitas ekonomi, tingkat pertumbuhan ekonomi yang tinggi dan pemerataan pendapatan6.Salah satu cara pemerintah untuk bisa mengatur kebutuhan pemerintahannya adalah dengan cara melaksanakan pungutan-pungutan daerah berdasarkan prestasi dan jasa yang diberikan kepada masyarakat sehingga keleluasaan retribusi daerah terletak pada yang dinikmati oleh masyarakat.

Menurut Marihot Pahala Siahaan retribusi daerah adalah pembayaran atas jasa atau pemberian izin tertentu yang khusus disediakan dan atau diberikan oleh pemerintah daerah untuk kepentingan orang atau badan7. Jasa adalah kegiatan pemerintah daerah berupa usaha dan pelayanan yang menyebabkan barang, fasilitas atau kemanfaatan lainnya yang dapat dinikmati oleh orang pribadi atau badan dengan demikian bila seseorang ingin menikmati jasa yang disediakan oleh pemerintah daerah maka ia harus membayar tarif yang ditetapkan sesuai dengan ketentuan yang berlaku. Jadi jika masyarakat akan menggunakan fasilitas yang disediakan oleh pemerintah, salah satunya fasilitas yang ada di pasar untuk melaksanakan transaksi jual beli dengan cara menyewa lapak, kios dan los yang ada di pasar maka masyarakat tersebut harus membayar tarif jasa pengelolaan pasar yang ditetapkan sesuai dengan ketentuan yang berlaku.

Didalam Islam membolehkan menyewakan tanah disyaratkan menjelaskan barang yang disewakan, baik itu berbentuk tanaman, tumbuhan atau bangunan. Jika yang dimaksud akan digunakan untuk pertanian maka harus dijelaskan, jenis apa yang ditanam tersebut, kecuali jika orang yang menyewakan mengizinkan ditanam apa saja yang dia kehendaki8.

Tujuan dan kebijakan fiskal dalam Islam adalah untuk 
menciptakan stabilitas ekonomi, tingkat pertumbuhan ekonomi yang tinggi dan pemerataan pendapatan9.Salah satu cara pemerintah untuk bisa mengatur kebutuhan pemerintahannya adalah dengan cara melaksanakan pungutan-pungutan daerah berdasarkan prestasi dan jasa yang diberikan kepada masyarakat sehingga keleluasaan retribusi daerah terletak pada yang dinikmati oleh masyarakat.

Didalam Islam membolehkan menyewakan tanah disyaratkan menjelaskan barang yang disewakan, baik itu berbentuk tanaman, tumbuhan atau bangunan. Jika yang dimaksud akan digunakan untuk pertanian maka harus dijelaskan, jenis apa yang ditanam tersebut, kecuali jika orang yang menyewakan mengizinkan ditanam apa saja yang dia kehendaki

\section{ASIL PENELITIAN DAN ANALISA PEMBAHASAN}

Pemerintah Kota Bandung mengeluarkan Peraturan Walikota Bandung Nomor 117 Tahun 2008 tentang Penetapan Tarif Jasa Perusahaan Daerah Pasar Bermartabat Kota Bandung, untuk membiayai keberadaan pasar seperti biaya pembangunan, biaya operasional, biaya pemeliharaan, biaya kebersihan dan biaya keamanan maka perlu ditetapkan besaran tarif jasa pengelolaan pasar.

dibayarkan oleh pengguna jasa atau pedagang kepada agen pengelola pasar adalah Rp.1200,- perhari.12 Perjanjian pihak pedagang dan pengelola pasar sudah melakukan akad sewa-menyewa (Ijarah) terlebih dahulu untuk menyewa kios tersebut serta kebersihan, ketertiban dan keamanannya sesuai dengan Peraturan Walikota Nomor 117 Tahun 2008 yang ada dalam Pasal 11 dan 12; sedangkan dalam implementasinya tarif jasa pengelolaan pasar yang di berlakukan di pasar Andir Bandung ini tidak sesuai dengan Peraturan Walikota Nomor 117 Tahun 2008 yang ada dalam Pasal 11 dan 1213, sehingga timbul rasa ketidakrelaan beberapa pedagang terhadap pembayaran pungutan tarif jasa pengelolaan pasar yang tidak sesuai dengan Peraturan Walikota Nomor 117 Tahun 2008 yang ada dalam Pasal 11 dan 12, serta hal ini pun bertentangan dengan syarat sah sewa menyewa (Ijarah) menurut Hukum Ekonomi Syariah.

Ketidaksesuaian antara maksud di awal dengan implementasinya di lapangan yakni kenaikan dan tambahan tarif jasa yang tidak sesuai dengan kesepakatan di awal akad ijarah, dan tidak terpenuhinya rukun dan syarat dari sewa- menyewa itu sendiri membuat tarif jasa pengelolaan pasar Andir Bandung ini tidak sah dan tidak dapat dibenarkan oleh Hukum Ekonomi Syari'ah, karena beberapa hal sebagai berikut, pertama; bahwa dalam rukun ijarah, syarat dua orang yang berakad yaitu mu'ajir (penyewa) dan musta'jir (yang menyewakan) selain harus berakal dan mumayyiz (dewasa), disyaratkan juga 'An'taradin, artinya kedua belah pihak berbuat atas kemauan sendiri. Sebaliknya, tidak dibenarkan melakukan upah-mengupah atau sewa-menyewa karena paksaan atau ketidak relaan salah satu pihak ataupun pihak lain. Kedua; syarat sah ijarah salah satu poinnya adalah persetujuan kedua belah pihak, dalam persetujuan kedua belah pihak terdapat shighat harus memenuhi syarat yaitu adanya persesuaian ijab dan kabul dapat dilakukan dengan lafaz atau ucapan untuk melakukan transaksi atau perjanjian. Dijadikan pedoman dalam ijab kabul adalah sesuatu yang dapat dipahami oleh dua orang yang melakukan akad sehingga tidak menimbulkan keraguan atau pertentangan. Atas dasar inilah dapat disimpulkan bahwa tidak terpenuhinya rukun dan syarat dari sewa- menyewa itu sendiri membuat tarif jasa pengelolaan pasar Andir Bandung ini tidak sah dan tidak dapat dibenarkan oleh Hukum Ekonomi Syari'ah.

\section{SIMPULAN DAN SARAN}

\section{A. Simpulan}

Pemerintah Kota Bandung mengeluarkan ${ }_{\text {Peraturan }}^{\text {Adarif jasa }}$ Walikota Bandung Nomor 117 Tahun 2008 tentang Penetapan Tarif Jasa Perusahaan Daerah Pasar Bermartabat Kota Bandung, untuk membiayai keberadaan pasar seperti biaya pembangunan, biaya operasional, biaya pemeliharaan, biaya kebersihan dan biaya keamanan maka perlu ditetapkan besaran tarif jasa pengelolaan pasar. Ada berberapa macam tarif jasa pengelolaan pasar perharinya yang terdapat pada Peraturan Walikota Bandung ini antara lain jasa kebersihan Rp.700,- perhari jasa ketertiban dan keamanan Rp.500,- perhari, maka jika ditotalkan tarif jasa pengelolaan pasar perharinya yang dibayarkan oleh pengguna jasa atau pedagang kepada agen pengelola pasar adalah Rp.1200,- perhari.

Berdasarkan hasil analisis adanya ketidaksesuaian antara maksud diawal perjanjian dengan implementasi di lapangan dan tidak terpenuhinya rukun dan syarat dari sewa menyewa menurut Hukum Ekonomi Syariah (HES) itu sendiri membuat tarif jasa pengelola pasar andir Bandung ini tidak sah dan tidak dapat dibenarkan. 